\title{
THE AMBIGUITY OF COVID-19 EFFECT ON THE LATVIAN FISHERY SECTOR
}

\author{
*Mihails Silovs, Irina Pilvere \\ Latvia University of Life Sciences and Technologies, Latvia \\ *Corresponding author’s email: Mihails.Silovs@1lu.lv
}

\begin{abstract}
The dramatic change in various spheres of daily life caused by the COVID-19 virus epidemic has had many ambiguous effects on the Latvian fisheries sector.

As part of a national research program project reCOVery-LV to study the virus's effect on the supply chain, LLU researchers concluded that Latvian fish processing demonstrates a multidirectional effect. The interpretation of statistics and the interviews conducted confirmed the hypothesis that the virus has had negative and positive effects within one sector of the economy. This industry heterogeneity places high demands on support criteria, making them more targeted for successful risk management. The research aims to analyze the fishery sector and identify the COVID-19 pandemic effect on Latvia's fish sector. As part of the study, all stages of the fish food chain were studied, risks were identified, their relative relevance was determined, and measures were proposed to neutralize these risks. This article summarizes the results of the study, prioritizes the implementation of countermeasures that reduce risks and are recommended by the results of the risk assessment, and complement the results of the study, identifies measures aimed at the long-term and sustainable development of the industry, based on the lessons of the COVID-19 pandemic.
\end{abstract}

Key words: COVID-19 effect, risk management, institutional measures, policy implications, fishery sector.

\section{Introduction}

The COVID-19 pandemic in Latvia has imposed several restrictions on all food system stages, including the fish food supply chain. The industry and consumption of fish products in Latvia are embedded in the global flows of fish raw materials and are subject to many risks affecting international supply and demand. Besides, the fishing industry is characterized by various fish raw materials, with different origins both from the European Union (EU) and surrounding countries and from far abroad.

The fish processing sector differs from other food industry sectors in various options for all food system stages. In particular, fish processing, depending on local and imported raw materials, meets local and export buyers' needs. As a result, many identified risks are characteristic only for some and generally do not apply to other enterprises in the sector. It makes it impossible to generalize about "self-sufficiency in fish in general". Fishers catch some types of fish, processors process others for a significant part, working mainly for export, and consumers consume the third, mostly imported.

The research aims to analyze the fishery sector and identify the COVID-19 pandemic effect on Latvia's fish sector. The following specific research tasks were set to achieve the aim: 1) to analyze the fishery sector in Latvia; 2) to identify the impact of the COVID-19 pandemic on the fish sector in Latvia.

\section{Materials and Methods}

As part of the study, interviews were conducted with fishers, fish breeders, and processors of different types of fish. The current state and impact of the COVID-19 pandemic on all stages of the food chain were studied. Targeted conclusions were made based on import-export statistics in the type of processing, type of fish, and relevant markets.

\section{Theoretical Background}

Building a sustainable food system is one of the EU Green Deal programs' objectives (Krämer, 2020). COVID-19 pandemic poses risks and affects the sustainability of all links in the food chain (Cullen, 2020), highlighting those bottlenecks in food chains that might have gone unnoticed in the absence of a crisis but demanded immediate solutions to avoid system collapse (Shay \& Murphy, 2020; Qin, 2020).

There is broad consensus over the definition of "risk" among leading national and international standards and guidelines, as well as professional bodies (Chapman, 1997; Project Management Institute, 2000). A typical two-dimensional definition of risk in the realm of management is "An uncertain event or condition that, if it occurs, has a positive or a negative impact on a project objective" (Project Management Institute, 2000). The impact of risk is a tangible value of downside "in the event of a risk." The likelihood is clear that this is a subjective perception of the interviewees, which cannot be calculated if only due to the current situation's uniqueness (Hillson $\&$ Hulett, 2004). Both in the study and this article, risks are ranked by combining these factors for the possibility of prioritization.

Many authors and international organizations state the pandemic consequences and suggest possible institutional solutions to emerging crises (FAO, 2020b), (OECD, 2020). Besides, many works are devoted to the situation and possible political decisions in the fishery sector (FAO, 2020a; Manlosa, Hornidge, \& Schlüter, 2021; Love et al., 2021). Specific risks and possible solutions are grouped 
according to the food chain stages and are described in the following parts.

\section{Results and Discussion}

Analysis of the Fishery Sector in Latvia

Consumption. Fish is a traditional food for Latvia due to its geography and history. Latvia residents consume $24.9 \mathrm{~kg}$ of fish per person per year, which is higher than the EU average $(24.5 \mathrm{~kg}$ ) and significantly higher than in neighboring Lithuania and Estonia (15.6 $\mathrm{kg}$ and $16.3 \mathrm{~kg}$, respectively). Regular consumers, namely those who eat fishery and aquaculture products at least once a month, mainly belong to $40-54$ and over 55. Young people (15-24) are less inclined to consume fish in Latvia and at the EU level. In this category, regular consumers cover $64 \%$ of the total, which is slightly lower than at the EU level (67\%). Latvians consume mostly fresh and smoked products; loose fish $(66 \%)$ is slightly less frequently consumed than at the EU level (68\%) (CSB, 2019).

Latvians spend on fish on average 4.7 times less than on meat and meat products, while on average in the EU, this figure is 4.4 times.

The full range of activities required to deliver fish and fishery products from production to the final consumer are complex. Each link in the chain is susceptible to being disrupted or stopped by impacts arising from COVID-19. The desired result, human consumption of fish and fishery products, can only be achieved by protecting the producer-buyer-seller links and each stage of the supply chain (FAO, 2020a).

Based on the risks associated with a change in consumer habits, a shortage of products in the store, and a drop in consumers' ability to pay, possible measures were developed to prevent and combat the consequences. Only the decline in the population's ability to pay fell into the category of Probable and Having a significant impact. One possible institutional measure is to reduce the VAT rate on food and government support for consumption - food receipts for specific categories of citizens. Besides, in times of crisis and a possible extension of food chains, products with extended shelf life are in high demand. Today, manufacturers cannot offer suitable products other than canned food, which causes excitement and excessive demand, which must be processed (by increasing production, storage capacity).

Production. The fishery industry in Latvia is characterized by using various raw materials (Figure 2).

Small pelagics make up the vast majority of fish caught in Latvia (92\%). Small pelagics are composed of both sprat (sprattus sprattus balticus) and Baltic

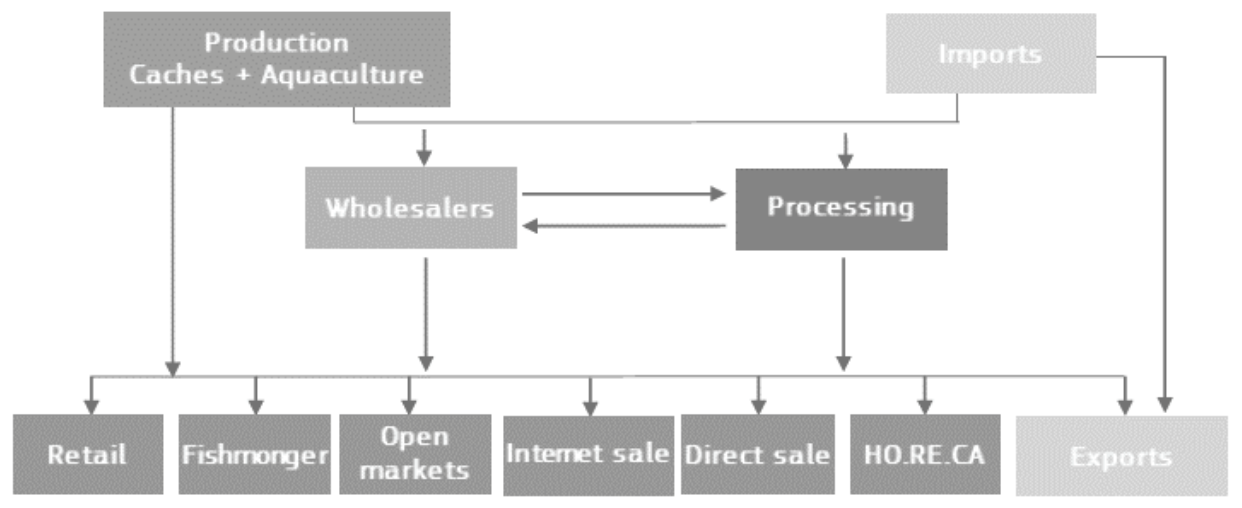

Figure 1. The Supply Chain of Fisheries and Aquaculture Products in Latvia.

Source: Authors' construction.

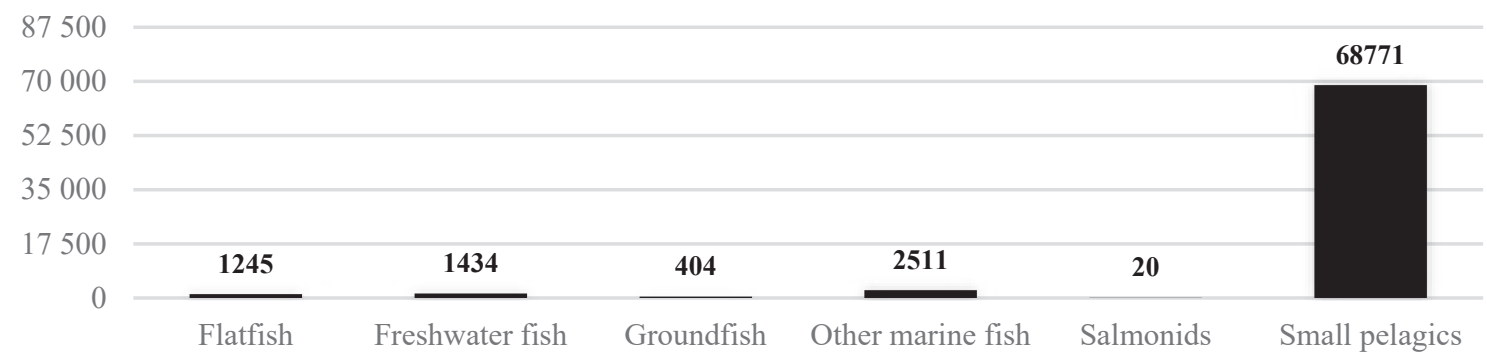

Figure 2. Raw Materials Landed in Latvia in 2018 (thousand tons).

Source: Zemkopības ministrija, 2019. 
herring (Clupea haeringus). In 2019, 601.9 tons of fish were grown in Latvia (aquaculture - Carp, Trout, Sturgeon), which is less than $1 \%$ of the wild fish caught.

Processing. Fish processing in Latvia in 2019 consisted of 130 companies (State Veterinary Service Register, Business Register) with a total turnover in 2019 of $238 \mathrm{~m}$ EUR. According to the data declared in the annual balance sheets, 3029 workers were employed at fish processing enterprises. Fish processing enterprises can be divided into two large groups - manufacturers of canned food and manufacturers of other fish products.

Historically, canned food producers have been in Latvia's territory (Ozolins et al., 2018). Production was specially developed in the second half of the 20th century when Latvian enterprises began to supply Eastern Europe and the former USSR territory. The development of production was due to an inadequate distribution network and, as a consequence, the need for products with a long shelf life.

Due to restrictions on working with the customs union and socio-economic and demographic factors, the number of enterprises producing canned food has significantly decreased. By the beginning of 2020, there were 13 enterprises in Latvia, with a total turnover of $100 \mathrm{~m}$ EUR. Besides, already in 2020, two more enterprises ceased production.

The second group of enterprises is processors of raw materials, which they receive from the EU and countries outside the EU. Such processors, or simply importers, enter the local market and are re-exported in processed form. The turnover of the companies from the second group in 2019 is $138 \mathrm{~m}$ EUR. The top 10 of these companies account for $85 \%$ of turnover (Table 1).
Both groups of companies (canned food producers and other fish processors) divide fish processing in Latvia into two practically equal groups - both in terms of turnover and companies. Both groups of companies were also affected by factors related to the pandemic. However, this influence was different due to the different situations of these companies.

On the one hand, fish processors producing products and canned fish, faced problems with the supply of raw materials, which to no small extent go for processing from abroad and often from outside the EU. Besides, processors faced declining demand for products with low shelf life.

On the other hand, both local and overseas demand for products with long shelf life has increased due to the epidemic. Historically, the Latvian industry has focused on producing such products in the form of canned fish. Given the increased demand, enterprises were able to load previously idle capacities. Until now, to a greater extent, enterprises have been able to maintain their activities and meet the growing demand. Nevertheless, the situation remains risky since canned food (primarily traditional canned food from local raw materials (small pelagics) is practically not mechanized and requires many people in one, which increases the risk of a rapid spread of the virus. Production of canned food from local raw materials significantly affects the increase in $\mathrm{CO}_{2}$ emissions.

Production and processing have various high-level risks caused by the COVID-19 pandemic. Primarily traditional canned food, but also more modern - is characterized by a large concentration of people. All possible technical and organizational, and technological measures are needed to counter the current situation's risks. Investments are also needed in the means of protecting workplaces and transport of workers.

The Top 10 Noncanned Fish Processors in Latvia in 2019

Table 1

\begin{tabular}{|l|c|c|l|}
\hline \multicolumn{1}{|c|}{ Company } & Sales 2019, EUR & Employees & \multicolumn{1}{c|}{ Characteristics } \\
\hline SIA 'Salas zivis' & 29556893 & 124 & Local, Baltic, EU, International wide variety. \\
\hline SIA 'Atlas Premium' & 26760793 & 143 & Cod processing, mainly export. \\
\hline SIA 'KH Select' & 19886478 & 156 & Salmon processing, mainly export. \\
\hline SIA 'Venta FM' & 9866492 & 31 & Fish meal. \\
\hline SIA 'RENETA' & 6069172 & 39 & Fish meal. \\
\hline SIA 'Gardumu karaliste' & 5868041 & 52 & Local, Baltic wide variety. \\
\hline SIA 'Mapeteks' & 4788659 & 18 & Fish meal. \\
\hline SIA 'Atlantika Surimi Seafood' & 4233933 & 58 & Surimi. \\
\hline SIA 'Taimiņš' & 3190604 & 29 & Local, Baltic wide variety. \\
\hline SIA 'Sudrablīnis' & 3190343 & 24 & Roe, caviar. \\
\hline All other companies & 22478672 & 613 & Wide variety. \\
\hline
\end{tabular}

Source: Authors' own based on data from Latvia Business Register, 2019. 


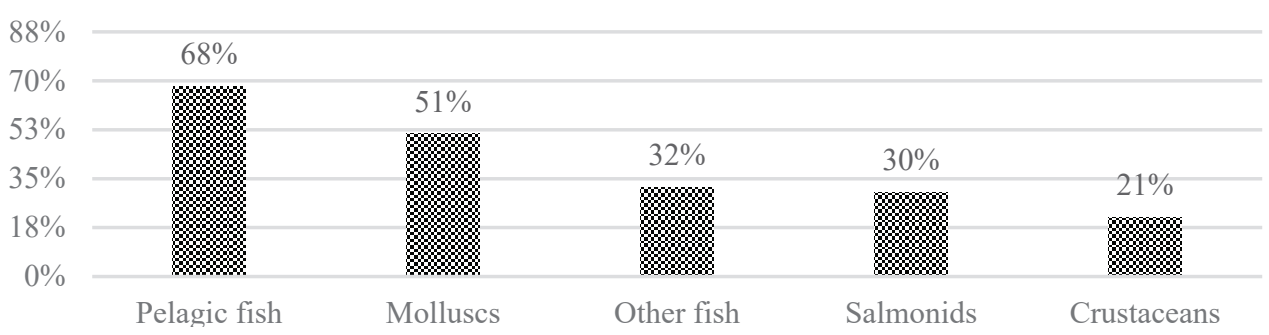

Figure 3. European Union's Self-Sufficiency Rate by Fish Commodity Group in 2017.

Source: Authors' calculations based on Eurostat and EUMOFA, 2020.

Moreover, all respondents confirmed additional costs related to regulatory changes and additional hygiene requirements. State support for the purchase of disinfectants and protection is possible.

The identified risks and possible measures go in line with those given in the documents issued by international organizations (FAO, 2020a).

Foreign trade. The value of EU trade of fisheries and aquaculture products, which comprises both extra-EU imports and exports, reached EUR 32.28 billion in 2018, making it the highest in the world. Of this, imports accounted for EUR 26.53 billion, which was $82 \%$ of the total. The EU is indeed a net importer, and the availability of these products in the domestic market mainly relies on extra-EU supplies. Low self-sufficiency of the EU in such a widely consumed species as Salmon (30\%, Figure 3), can cause shortages due to additional controls and delays on the EU borders.

Latvia is closely linked to these flows, receiving most of the fish and fish products from abroad. The overall trade balance shows that the countries outside the EU are more partners in marketing than supplying raw materials. Besides, total exports outside the EU and EEA account for only $22 \%$ of total exports and $7 \%$ of total imports.

Looking at the trade balances by fish species, we see that the EU and EEA countries provide the most significant raw materials supplied to Latvia. As for salmon, bearing in mind that Europe provides itself only for $30 \%$ (Figure 3), as well as the origin of the majority of imports from the EU - Sweden, Lithuania, Finland, and Poland - we can conclude that mainly Norwegian farmed salmon enters the Latvian market. Likewise, most of the cod for processing in Latvia comes from Sweden. However, the country of origin of the cod is Norway or Iceland. These two fish varieties cover most of the activities of two large fish portioning companies, some salmon canning companies, and local consumption. Mackerel, purchased from Iceland and Norway, is processed and supplied mainly to the EU and UK markets.

Table 2

Trade Balance of Latvia by Types of Raw Materials for the 2020 (January-August), EUR

\begin{tabular}{|l|c|c|c|c|}
\hline \multicolumn{1}{|c|}{ Fish } & EU & EEA + THE UK & Non-EU & Grand Total \\
\hline Salmonids & -9579992 & -4647403 & 1637247 & -1290148 \\
\hline Miscellaneous aquatic products & -5256623 & -284733 & -260377 & -5801733 \\
\hline Groundfish & -12791563 & 8858137 & 774942 & -3158484 \\
\hline Crustaceans & -2444450 & -78892 & -209157 & -2732499 \\
\hline Other marine fish & -2001569 & -350566 & -72612 & -2424747 \\
\hline Small pelagics (other) & 327594 & -1268361 & -29708 & -970475 \\
\hline Tuna and tuna-like species & 403116 & 1796 & -1062374 & -657462 \\
\hline Freshwater fish & -405306 & 16380 & -260808 & -649734 \\
\hline Bivalves and other molluscs and aquatic invertebrates & -486433 & 30112 & -187834 & -644155 \\
\hline Flatfish & -134025 & -261259 & 7651 & -387633 \\
\hline Cephalopods & -235378 & & -929 & -236307 \\
\hline Small pelagics (Mackerel) & 16500912 & -8397294 & 79059 & 8182677 \\
\hline Small pelagics (Sprat) & 15973303 & -1403422 & 20902844 & 35472725 \\
\hline Grand Total & $\mathbf{- 1 3 0 4 1 4}$ & $\mathbf{- 7 7 8 5 5 0 5}$ & $\mathbf{2 1 ~ 3 1 7 9 4 4}$ & $\mathbf{1 3 4 0 2 ~ 0 2 5}$ \\
\hline
\end{tabular}

Source: Authors' calculations based on Eurostat international trade statistics and EUMOFA. 
Trade Balance of Latvia by Type of Fish Processing Products for the 2020 (January-August), EUR

\begin{tabular}{|l|c|c|c|}
\hline Fish & EEA + THE UK & EU & Non-EU \\
\hline Frozen fish & -16327928 & -13720265 & 2832037 \\
\hline Fresh or chilled fish & -1070994 & -18011588 & \\
\hline Crustaceans & -60771 & -2440548 & -5699 \\
\hline Molluscs & 30352 & -710223 & -188850 \\
\hline Live fish & & -202819 & -16650 \\
\hline Aquatic invertebrates & -240 & -8661 & \\
\hline Fish fillets & 5868394 & -2989892 & 107571 \\
\hline Fish, dried, salted, or in brine, smoked fish & 56498 & 5684308 & -490559 \\
\hline Prepared or preserved fish & 4247136 & 32801974 & 18684563 \\
\hline Grand Total & $\mathbf{- 7 2 5 7 5 5 3}$ & $\mathbf{4 0 2 ~ 2 8 6}$ & $\mathbf{2 0 ~ 9 2 2 ~ 4 1 3}$ \\
\hline
\end{tabular}

Source: Authors' calculations based on Eurostat international trade statistics and EUMOFA, 2020.

Receiving frozen and chilled fish from the countries of the free economic zone (Iceland and Norway), as well as the EU countries, the enterprises of the industry ensure domestic consumption, as well as send fish in processed form (cut fish, smoked fish, canned fish) as to the EU countries and countries outside the EU. In the first eight months of 2020, the total import volume was $116 \mathrm{~m}$ EUR, and the export volume was $129 \mathrm{~m}$ EUR. Moreover, exports to countries outside the EU significantly exceeded imports (29.2 versus $7.8 \mathrm{~m}$ EUR).

Impact of COVID pandemic on foreign trade and apparent consumption

By comparing the trade balance by type of fish, we can assess the impact of the industry's current situation. The balance for fresh or chilled fish decreased in favor of an increase in frozen fish. The positive balance (more than exports than imports) for finished canned goods also increased.

Considering the change in exports and imports by types of fish (Figure 5) and processing types (Figure
6) separately, we find the crisis's main characteristics (lengthening of supply chains, possible closure of markets (Q in 2020). Such characteristics include Increased demand for products with an extended shelflife; Reducing the use of fresh or chilled fish in favor of frozen; Decreased production of more expensive fresh salmon products; Decreased production of fresh or chilled food.

It is necessary to diversify the supply, accumulate the necessary stocks of raw materials, and adapt production capabilities to the lengthening of the supply chain for raw materials and distribution of goods to ensure the sustainability of the food system in international trade.

Risks associated with international trade include potential border delays and general market uncertainty.

The proposed institutional measures include both direct support to enterprises and the introduction of tax preferences.

Risks. Below is a summary of the average risk values (impact* likelihood) for producers and fishers.

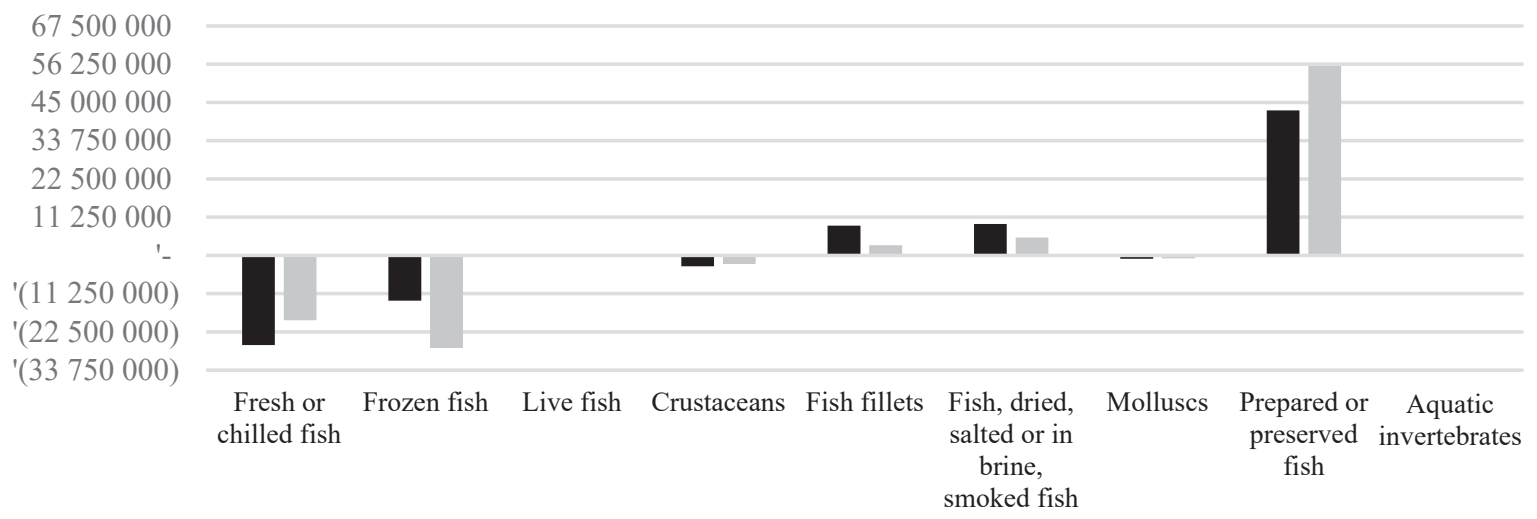

Figure 4. Trade Balance, 2019 (January-August) and 2020 (January-August) in Latvia, EUR.

Source: Authors' calculations based on Eurostat international trade statistics and EUMOFA. 
Export, 2019 (jan-aug) and 2020 (jan-aug), EUR

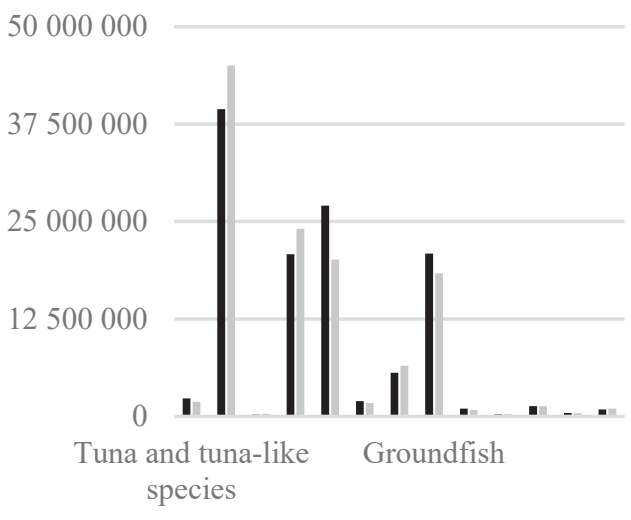

Import, 2019 (jan-aug) and 2020 (jan-aug), EUR

50000000

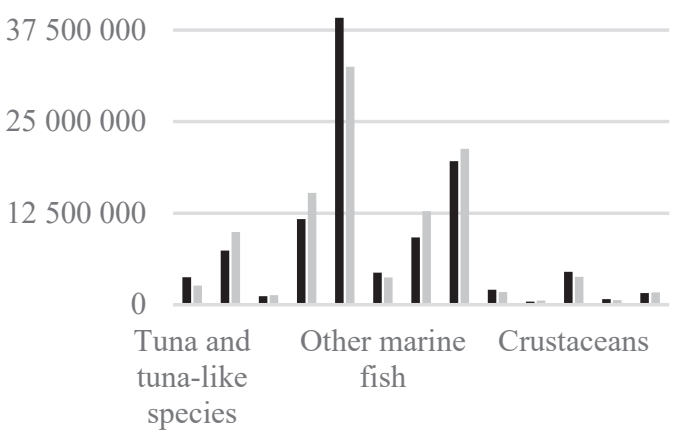

Figure 5. Trade Balance by Type of Fish in 2019 (January-August) and 2020 (January-August) in Latvia, EUR.

Source: Authors' calculations based on Eurostat international trade statistics and EUMOFA.
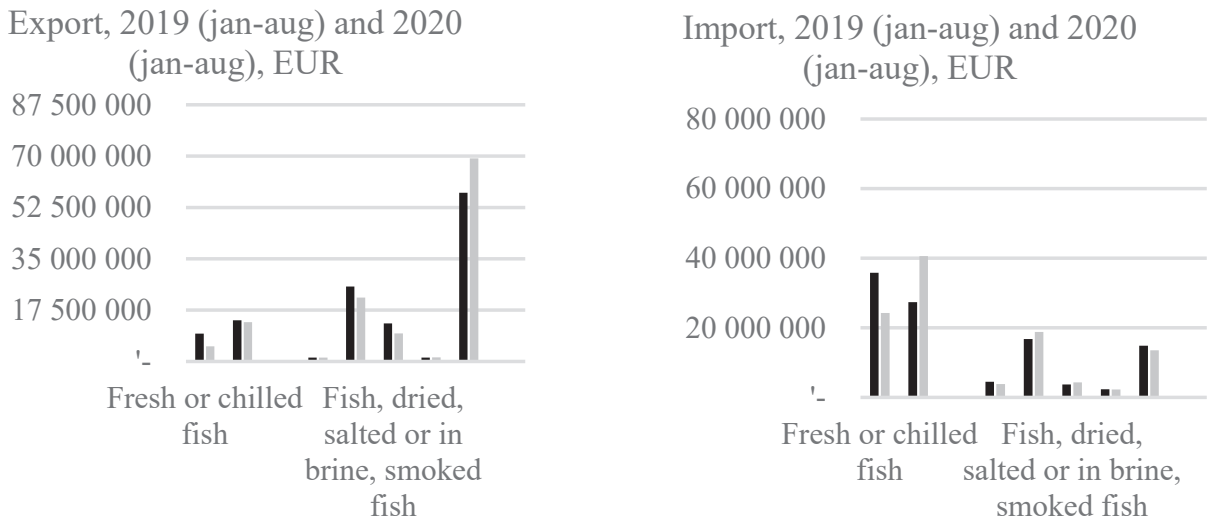

Figure 6. Trade Balance by Type of Fish Processing Products in 2019 (January-August) and 2020 (January-August) in Latvia, EUR.

Source: Authors' calculations based on Eurostat international trade statistics and EUMOFA.

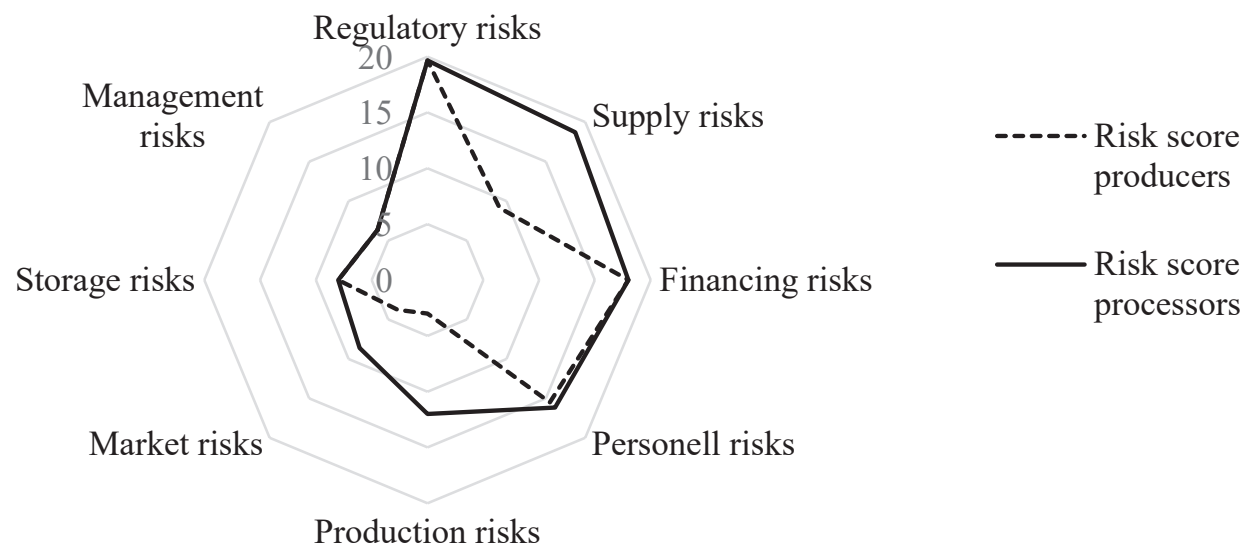

Figure 7. Risk Distribution in Fish Sector in COVID-19 Pandemic in Latvia.

Source: Authors' construction based on interviews with fish processors. 
The perception of these risks coincides in almost all categories, except for the supply of raw materials (producers have no limited access to raw materials), as well as the risks associated with the organization of production (the organization of the catch is less susceptible to the risks of a pandemic).

It should be noted that some risks (highlighted in the Figure 7) have fundamental causes, and the COVID-19 pandemic has only highlighted bottlenecks in a sustainable food chain. In particular, the industry's dependence on manual labor (personnel risks) (European Commission Joint..., 2020), the dependence of local consumption on imported raw materials (supply risks), as well as the lack of production of a mass consumption product with an extended shelf life, to meet the changing needs of consumers (market risks).

Long-term support for the industry could be institutional measures to stimulate $R \& D$ aimed at creating products with an extended shelf-life as a more nutritious and sustainable alternative to canned food (Tan \& Culaba, 2009). Moreover, such measures might stimulate the processing of local raw materials and promote the expansion of the range of products produced in the country to replace the import of fish with high added value. Finally, a long-term measure to strengthen the industry's sustainability could be to stimulate the automation and mechanization of processes currently employing a large number of people.

\section{Conclusions}

1. This article analyzes the identified risks and possible measures identified in the reCOVeryLV study. The key risks are the uncertainty of regulatory changes, risks associated with ensuring financial flow, and personnel risks. Besides, given some producers' dependence on imported raw materials, the supply risk is also significant.

2. This article uncovers the multidirectional effect of the COVID-19 pandemic on the fish sector in
Latvia. On the one hand, both in Latvia and abroad increased the consumption of products with extended shelf life (canned food). This allowed for the increase in the turnover of Latvian canned fish producers. On the other hand, factories that process imported fish were forced to switch from fresh to frozen raw materials to reduce the risk of product spoilage due to logistics delays.

3. The necessary institutional measures identified in the reCOVery-LV study include reducing producers and fish processors' costs for adapting to regulation changes, increasing financial stability, and ensuring the labor force's safe provision. Such measures include direct and indirect financial support, awareness-raising activities.

4. This article sets out the fundamental reasons for some of the risks. These fundamental reasons include the industry's dependence on manual labor, the production of a single product with the limited market within the country, and the lack of production of products that meet consumption habits changed by the pandemic. In particular nutritious ready-made fish products with an extended shelf life. A measure aimed at addressing these fundamental industry problems could be facilitating access to $R \& D$ in automation and new product development by reducing transaction costs at all stages of development. However, the development of specific institutional mechanisms aimed at reducing fundamental risks requires further research.

\section{Acknowledgments}

The paper was supported by the National Research Programme "Towards the Post-pandemic Recovery: Economic, Political and Legal Framework for Preservation of Latvia's Growth Potential and Increasing Competitiveness" (reCOVery-LV), Project Agreement: VPP-COVID-2020/1-0010.

\section{References}

Chapman, Ch. (1997). Project Risk Analysis and Management-PRAM the Generic Process. International Journal of Project Management, Vol. 15 (5), pp. 273-81. DOI: 10.1016/S0263-7863(96)00079-8.

CSB (2019). MBG151. Mājsaimniecības patēriņa izdevumu detalizēts sastāvs (ECOICOP) vidēji uz vienu mājsaimniecības locekli gadā (Euro). (Detailed composition of household consumption expenditure (ECOICOP) on average per household member per year). Retrieved January 12, 2021, from http://data1.csb. gov.lv/pxweb/lv/sociala/sociala__mb_izdevumi/MBG151.px/table/tableViewLayout1/?rxid=e13fe634b721-444c-ac0e-3047a0b2c86f. (in Latvian).

Cullen, M.T. (2020). COVID-19 and the Risk to Food Supply Chains: How to Respond? FAO, 7 p. Retrieved February 20, 2021, from http://www.fao.org/policy-support/tools-and-publications/resources-details/ en/c/1269383/.

European Commission Joint Research Centre Scientific, Technical and Economic Committee for Fisheries (2020). The EU Fish Processing Sector: Economic Report (STECF 19 15). LU: Publications Office. Retrieved February 7, 2021, from https://data.europa.eu/doi/10.2760/30373. 
Eurostat international trade statistics (2020). Extra-EU trade since 2000 by mode of transport, by HS2-4-6.

EUMOFA. The EU Fish Market: 2020 Edition. Publications Office, 2020.

FAO (2020a). How Is COVID-19 Affecting the Fisheries and Aquaculture Food Systems. FAO, 5 p. DOI: $10.4060 / \mathrm{ca} 8637 \mathrm{en}$.

FAO (2020b). Legal Considerations in Responses to COVID-19 to Mitigate the Risk of Disruption to Fisheries and Aquaculture Food Systems. FAO, 9 p. DOI: 10.4060/ca9421en.

Hillson, D., \& Hulett, D. (2004). Assessing Risk Probability: Impact Alternative Approaches. Retrieved February 18, 2021, from https://www.pmi.org/learning/library/assessing-risk-probability-impact-alternativeapproaches-8444.

Krämer, L. (2020). Planning for Climate and the Environment: The EU Green Deal. Journal for European Environmental \& Planning Law 17 (July), pp. 267-306. DOI: 10.1163/18760104-01703003.

Love, D.C., Allison, E.H., Asche, F., Belton, B., Cottrell, R.S., Froehlich, H.E., Gephart, J.A., Hicks, Ch.C., Little, D.C., Nussbaumer, E.M., da Silva, P.P., Poulain, F., Rubio, A., Stoll, J.S., Tlusty, M.F., Thorne-Lyman, A.L., Troell, M., \& Zhang, W. (2021). Emerging COVID-19 impacts, responses, and lessons for building resilience in the seafood system. Global Food Security, Vol. 28, 11 p. DOI: 10.1016/j.gfs.2021.100494.

Manlosa, A.O., Hornidge, A.K., \& Schlüter, A. (2021). Aquaculture-capture fisheries nexus under Covid-19: impacts, diversity, and social-ecological resilience. Maritime Studies, Vol. 20, pp. 75-85. DOI: 10.1007/ s40152-021-00213-6.

OECD (2020). Food Supply Chains and COVID-19: Impacts and Policy Lessons - OECD. Retrieved February 11, 2021, from https://read.oecd-ilibrary.org/view/?ref=134_134305-ybqvdf0kg9\&title=Food-SupplyChains-and-COVID-19-Impacts-and-policy-lessons.

Ozolins, J., Nipers, A., Pilvere, I., Silovs, M., \& Dmitrijeva, O. (2019). Potential investment Project for innovative product manufacturing from Baltic Sea sprats. In: $19^{\text {th }}$ International multidisciplinary scientific GeoConference SGEM 2019: conference proceedings, Albena, Bulgaria, 30 June-6 July, 2019, Bulgarian Academy of Sciences Sofia, Vol. 19, Issue 3.1: Water resources. Forest, marine and ocean ecosystems. Section: Hydrology and water resources. Marine and ocean ecosystems, pp. 723-731. DOI: 10.5593/ sgem2019/3.1/S12.092.

Project Management Institute ed. (2000). A Guide to the Project Management Body of Knowledge (PMBOK Guide). Newtown Square, Penn., USA: Project Management Institute.

Shay, E., \& Murphy, L. (2020). A Shock to the Food System Lessons Learned from the COVID-19 Pandemic. Deloitte, 22 p. Retrieved February 22, 2021, from https://www2.deloitte.com/content/dam/Deloitte/global/ Documents/Consumer-Business/gx-cb-a-shock-to-the-food-system.pdf.

Qin, A. (2020). Coronavirus Fears in China Find a New Target: Salmon. The New York Times, June 19, 2020 , sec. World. Retrieved February 25, 2021, from https://www.nytimes.com/2020/06/18/world/asia/coronaviruschina-salmon.html.

Tan, R., \& Culaba, A. (2009). Estimating the Carbon Footprint of Tuna Fisheries. WWF Bin Item, January.

Zemkopības ministrija (2019). Latvijas Zivsaimniecības Gadagrāmata 2019. Latvijas Lauku konsultāciju un izglītības centrs. (Latvian Fisheries Yearbook 2019). Latvian Rural Advisory and Education Center. (in Latvian). 